\title{
Pemberdayaan Masyarakat Melalui Pemanfaatan Jerami Jagung Sebagai Pakan Ternak Di Desa Leu Kecamatan Bolo Kabupaten Bima
}

\author{
Oscar Yanuarianto*, Mastur, Intan Putri Mantika, Ica Ayu Wandira, Burhan \\ Program Studi Diploma III Produksi Ternak Program Vokasi Universitas Mataram \\ Pendidikan Diluar Domisili (PDD) Kabupaten Bima \\ Jl. Majapahit 62 Mataram, Nusa Tenggara Barat 83125, Indonesia
}

Article history

Received: 13-10-2020

Revised: 04-11-2020

Accepted: 24-11-2020

*Corresponding Author:

Oscar Yanuarianto,

Program Studi Diploma III

Produksi Ternak Program

Vokasi Universitas Mataram

Pendidikan Diluar Domisili

(PDD) Kabupaten Bima,

Nusa Tenggara Barat,

Indonesia

Email: oscary338@gmail.com
Abstract: Currently, corn has become one of the leading commodities. This commodity can replace traditional crops such as green beans and soybeans which have a high risk of failure and require extra care. On the other hand, the use of corn waste products such as corn stover as animal feed is an efficient effort to meet feed needs, which in turn increases farmers' income and reduces the problem of environmental pollution due to corn straw waste. Leu village is one of the corn plant cultivation centers in Bima Regency, therefore, it is very necessary to improve the community's ability to utilize corn straw as animal feed; one of them is through community empowerment service activities that we have done. Community empowerment activities were attended by more than 20 participants including farmers, village officials, and extension office staff. Extension activities are carried out through demonstrations, orations (extracurricular lectures and discussions), and leaflet distribution. The results of community empowerment service activities were felt to be very useful; this was shown by the enthusiasm of the extension participants who were present during the activity.

Keywords: community; empowerment; service; corn; animal-feed

Abtrak: Tanaman jagung saat ini telah menjadi salah satu komoditi unggulan. Komoditas ini mampu menggantikan tanaman tradisional berupa kacang hijau dan kacang kedelai yang memiliki risiko kegagalan tinggi dan membutuhkan perawatan yang ekstra. Di sisi lain, pemanfaatan limbah jagung seperti jerami jagung sebagai pakan ternak merupakan upaya yang efisien dalam pemenuhan kebutuhan pakan, yang selanjutnya meningkatkan pendapatan petani serta mengurangi masalah pencemaran lingkungan akibat limbah jerami jagung. Desa Leu merupakan salah satu desa sentra budidaya tanaman jagung di Kabupaten Bima, oleh karena itu, sangat perlu untuk ditingkan kemampuan masyarakatnya dalam memanfaatkan jerami jagung sebagai pakan ternak; salah satunya yaitu melalui kegiatan pengabdian pemberdayaan masyarakat yang telah kami lakukan ini. Kegiatan pengabdian pemberdayaan masyarakat diikuti oleh lebih dari 20 orang peserta yang meliputi petani peternak, perangkat desa dan staf extention office. Kegiatan penyuluhan dilakukan melalui demonstrasi, orasi (ceramah dan diskusi), dan penyebaran leaflet. Hasil kegiatan pengabdian pemberdayaan masyarakat dirasa sangat bermanfaat, hal ini ditunjukkan oleh antusiasnya peserta penyuluhan yang hadir selama kegiatan berlangsung.

Kata Kunci: pengabdian; pemberdayaan; masyarakat; jagung; pakan 


\section{PENDAHULUAN}

Seperti di beberapa tempat, di daerah Nusa Tenggara Barat termasuk Bima, tanaman jagung merupakan primadona baru di bidang pertanian. Hampir seluruh lahan pertanian, terutama area ladang umumnya digunakan sebagai lahan untuk menanam jagung. Tiga tahun terakhir, warga NTB termasuk warga Bima gencar melakukan budidaya tanaman jagung. Komoditas ini mampu menggantikan tanaman tradisional berupa kacang hijau dan kacang kedelai yang perawatannya dianggap sulit dan memiliki risiko kegagalan cukup tinggi.

Pada sisi lain, pemanfaatan sumber daya pertanian tanaman jagung dalam bentuk limbah seperti jerami jagung sebagai sumber pakan ternak merupakan langkah efisiensi dalam pemenuhan kebutuhan pakan ternak sekaligus mengatasi permasalahan pencemaran lingkungan akibat ketidak manfaatan limbah yang dihasilkan dari kegiatan pertanian. Selain itu, pemanfaatan jerami jagung juga dipandang mampu meningkatkan pendapatan petani. Disamping dapat mengkomersilkan komoditas utama dari tanaman jagung yang berupa biji jagung, petani juga dapat mengkomersilkan limbah jerami jagung untuk dijadikan bahan pakan ternak. Akan tetapi, pemanfaatan limbah jerami jagung ini masih sangat minim dilakukan oleh para petani dikarenakan pengetahuan dan pemahaman terkait hal tersebut masih sangat minim (Umela dan Syaiful., 2016)

Kewajiban setiap Perguruan Tinggi sebagaimana dijelaskan dalam Tridharma Perguruan Tinggi adalah Pendidikan, Penelitian, dan Pengabdian Masyarakat. Melalui kegiatan pengabdian pada masyarakat diharapkan ilmu-ilmu dan teknologi terbaru mampu ditransfer dan diaplikasikan oleh masyarakat guna mengatasi masalah-masalah yang sering dihadapi sekaligus meningkatkan kesejahteraannya. Oleh karena itu, salah satu pengabdian pada masyarakat yang direncanakan oleh Program Vokasi Universitas Mataram PDD Bima tahun 2019 adalah meberikan penyuluhan dan demonstrasi mengenai pemanfaatan jerami jagung sebagai pakan ternak. Mempertimbangkan mayoritas masyarakat desa Leu yang saat ini tengah menggeluti usaha budidaya tanaman jagung, maka dipilihlah desa Leu sebagai lokasi sasaran kegiatan pengabdian pada masyarakat kali ini yang mengangkat judul "Pemberdayaan Masyarakat Melalui Pemanfaatan Jerami Jagung Sebagai Pakan Ternak Di Desa Leu Kecamatan Bolo Kabupaten Bima”. Adapun tujuan dari kegiatan ini adalah untuk meningkatkan pengetahuan petani peternak desa Leu Kecamatan Bolo tentang pemanfaatan limbah pertanian dan teknologi pengolahan limbah pertanian sebagai pakan ternak.

\section{METODE}

Sasaran kegiatan pemberdayaan masyarakat melalui pemanfaatan jerami jagung sebagai pakan ternak ini adalah masyarakat Desa Leu Kecamatan Bolo Kabupaten Bima yang saat ini tengah banyak menggeluti usaha budidaya tanaman jagung. Kegiatan pengabdian ini bekerja sama dengan pemerintah desa Leu kecamatan Bolo, hal ini dilakukan terutama dalam rangka mengidentifikasi masyarakat serta mengorganisir mereka untuk mengikuti kegiatan pengabdian tersebut. Selain itu kerjasama dengan pemerintah desa juga dimaksudkan untuk mengidentifikasi lokasi sebagai tempat penyuluhan, demonstrasi dan pelatihan sebagai rangkaian kegiatan pengabdian ini.

\section{Persiapan Pelaksanan Kegiatan}

Metode pendekatan dalam kegiatan pengabdian kepada masayarakat ini adalah penyuluhan dan pendidikan singkat dengan cara ceramah, diskusi dan memberikan contoh tentang hal-hal yang 
terkait dengan program yang akan disampaikan. Sebelum pelaksanaan kegiatan perlu dilakukan koordinasi dengan Puskeswan, Kepala Desa, Kepala Dusun dan Kelompok Peternak agar pelaksanaan kegiatan berjalan degan baik, lancar dan berhasil. Koordinasi yang dilakukan adalah untuk menentukan waktu dan tempat pelaksanaan serta komponen masyarakat yang mengikuti kegiatan pengabdian kepada masyarakat.

Sasaran kegiatan pengabdian kepada masyarakat ini adalah para petani peternak Desa Leu Kecamatan Bolo Kabupaten Bima. Realisasi pemecahan masalah dilakukan dengan cara penyuluhan dan pendidikan singkat melalui ceramah dan diskusi. Apabila terdapat permasalahan yang terkait persiapan dan pelaksanaan penerapan teknologi, maka perlu dilakukan pembinaan lanjutan.

\section{Pelaksanaan dan Evaluasi Hasil Kegiatan}

Peserta penyuluhan diberikan ceramah dan demonstrasi tentang teknik pengolahan limbah pertanian khususnya limbah jagung sebagai pakan Aplikasi teknologi ini diharapkan dapat meningkatkan produksi serta efisiensi usaha beternak ruminansia yang bernilai ekonomis. Pelaksanaan kegiatan pengabdian kepada masyarakat ini berjalan lancar. Kegiatan diikuti oleh Kepala Desa dan Kelompok Peternak serta masyarakat lainya yang belum masuk dalam kelompok. Masyarakat mengikuti seluruh rangkaian kegiatan penyuluhan dengan penuh perhatian dan antusias hingga akhir acara.

Diskusi berlangsung dengan baik, hangat dan lancar. Pada akhir kegiatan penyuluhan juga dilakukan evaluasai terhadap faktor-faktor pendukung dan penghambat kelancaran dan keberhasilan kegiatan pengabdian kepada masyarakat ini. Apabila diperlukan, ketika terdapat permasalahan yang terkait persiapan dan pelaksanaan penerapan teknologi ini di masyarakat, maka tim penyuluh siap mengadakan pembinaan lanjutan.

\section{HASIL DAN PEMBAHASAN}

Lingkungan mengambil $75 \%$ pengaruh terhadap produktivitas ternak. Salah satu faktor lingkungan yang sangat berpengaruh terhadap produktivitas ternak adalah pakan (Mayasari, dkk., 2013)., Oleh karena itu, selain kandungan nutrisinya yang harus dipertahankan, kontiyuitas dari pakan juga perlu diperhatikan. Ketersediaan pakan yang umumnya sangat berlimpah pada musim hujan sedangkan sangat minim pada musim kemarau menyebabkan kualitas dan kuantitas pakan pada musim kemarau menurun cukup drastis. Ditambah lagi penyediaan pakan peternak yang masih sangat bergantung pada ketersedian rumput lapangan menyebabkan peternak harus berusaha ekstra untuk mendapatkan pakan pada musim kemarau.

Disisi lain, sebagai daerah yang masyarakatnya lebih banyak bermata pencaharian sebagai petani, maka tentu saja di daerah ini akan diproduksi limbah pertanian yang cukup banyak, termasuk limbah jerami jagung. Ketidak efektifan memanfaatkan limbah ini umumnya dapat menyebabkan pencemaran lingkungan, karena untuk menghilangkan limbah tersebut masyarakat desa memilih cara dengan membakar. Proses pembakaran ini justru dapat menimbulkan polusi udara yang juga dapat berdampak buruk pada kesehatan manusia. Padahal jika limbah tersebut dimanfaatkan secara efektif dan efisien seperti mengolahnya menjadi pakan ternak, maka selain mengurangi pencemaran lingkungan, petani peternak juga justru akan memperoleh keuntungan lebih karena pakan dapat diperoleh dengan mudah dan harga yang terjangkau atau bahkan secara gratis. 
Kegiatan pengabdian yang dilaksanakan pada tanggal 22 Juli 2019 melibatkan 42 orang peserta. Peserta terdiri dari berbagai kalangan termasuk di dalamnya adalah para petani jagung, peternak sapi dan kambing, serta para aparatur Desa Leu. kegiatan pengabdian dikemas dalam bentuk ceramah dan diskusi lalu dilanjutkan dengan demosntrasi dan pelatihan. Selain diberikan materi mengenai pemanfaatan jerami jagung sebagai pakan ternak, peserta juga diajarkan langsung bagaimana cara membuat silase jagung sebagai salah satu jenis pakan yang dapat diproduksi dari limbah jerami jagung.

Respon peternak terhadap kegiatan pengabdian terlihat cukup baik. Hal ini terlihat dari antusiasme para peternak dalam menerima materi yang diberikan dan keikutsertaan mereka dalam mempraktekan pembuatan fermentasi jerami dan kompos. Selain itu petani peternak juga sangat aktif dalam berbagi pengalaman serta mengungkapkan masalah-masalah yang sering dihadapi selama bertani maupun beternak. Peserta juga berharap bahwa kegiatan yang praktis dan aplikatif diterapkan oleh masyarakat seperti ini harus sering dilakukan guna meningkatkan kecakapan mereka dalam bidang yang mereka geluti. Berikut adalah beberapa gambar pada saat dilakukan kegiatan pengabdian.
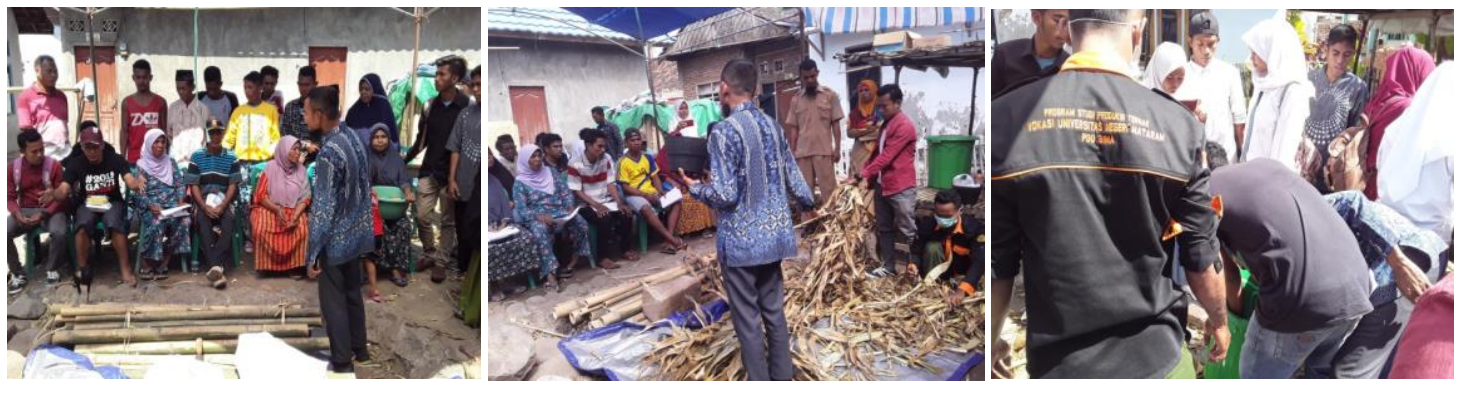

Gambar 1. Penyampaian materi dan diskusi tentang pemanfaatan jerami jagung sebagai pakan dan aktivitas masyarakat dalam demontrasi pembuatan silase jagung.

Hasil langsung dari kegiatan pengabdian yang dilakukan di Desa Leu Kecamatan Bolo Kabupaten Bima ini terlihat dari antusiasme para peserta serta perubahan prilaku peternak yang mulai memanfaatkan limbah pertanian disekitarnya untuk dijadikan pakan ternak melalui teknologi silase. Masyarakat akhirnya sadar bahwa beternak dan bertani merupakan dua kegiatan yang dapat saling memberikan keuntungan. Masyarakat juga merasa sangat antusias karena akhirnya mereka mendapatkan pengetahuan bagaimana cara mengatasi masalah kekurangan pakan ketika musim kemarau dengan cara yang efektif dan efisien. Hal ini menunjukkan bahwa peternak mulai berpikir secara agribisnis dimana mereka memanfaatkan limbah untuk menunjang kegiatan produksi mereka tanpa mengeluarkan biaya besar.

Meningkatkan pengetahuan dan pemahaman masyarakat petani peternak di Desa Leu dan sekitarnya tentang teknik pengolahan limbah jagung sebagai pakan ternak dapat dilihat dari aktifnya meraka dalam sesi diskusi serta pada saat demonstrasi setelah penyampaian materi oleh penyuluh, adapun materi yang telah disampaikan di antaranya :

\section{Cara Membuat Silase Untuk Pakan Ternak}

Pada wilayah kegiatanseperti halnya wilayah-wilayah lainnya di Indonesia yang terdapat dua musim, musim hujan dan musim kemarau, menjadi perhatian penting bagi peternak yang memelihara ternak seperti sapi, kambing, domba dll. Karena terbatasnya rerumputan pada musim kemarau. 
Melimpahnya hijauan pada musim hujan adalah sauatu kesempatan bagi peternak untuk menyimpan pakan hijauannyauntuk musim kemarau. Tapi bagaimana caranya pakan hijauan tersebut yang disimpan tidak kering dan nilai gizi atau protein tidak berkurang, dan pakan hijauan tersebut dapat disimpan selama 1 bulan, 2 bulan atau 6 bulan bahkan 1 tahun. Untuk itu diperkenalkan salah satu lagi teknologi pengewatan pakan hijaun ternak yaitu Silase.

Pakan hijaun yang telah dipotong dari lahan seperti Rumput Gajah, kemudian dikeringkan dengan kandungan air 60\% sebelum disimpan dalam kondisi tertutup tanpa udara atau yang biasa disebut anearob.

Kenapa pakan hijauannya ini perlu dikeringkan? Pengeringan ini dilakukan untuk mengurangi kadar air hijaun, jadi pakan hijauan ini tidak dapat cepat rusak. Pengeringan bisa dilakukan dengan menggunakan mesin pengering, atau mau lebih hemat bisa dijemur bentar dibawah terik matahari.

Silase merupakan pakan hijauan ternak yang diawetkan yang disimpan dalam kantong plastik yang kedap udara atau silo, drum, dan sudah terjadi proses fermentasi dalam keadaan tanpa udara atau anaerob. Proses silase ini melibatkan bakteri-bakteri atau mikroba yang membentuk asam susu, yaitu Lactis Acidi dan streptococcus yang hidup secara anerob dengan derajat keasaman 4 ( $\mathrm{pH} 4$ ).

Oleh karena itu mengapa pada saat proses silase pakan hijauan ternak yang tersimpan dalam kantong plastik atau dalam silo harus ditutup rapat, sehingga proses silase berjalan dengan baik dan pakan hijauan tidak cepat dibusukkan oleh bakteri lain dan jamur.

\section{Tujuan Membuat Silase Untuk Pakan Ternak}

1. Sebagai cadangan dan persediaan pakan ternak pada saaat musim tanpa penghujan (kemarau) yang panjang.

2. Untuk meyimpan dan menampung pakan hijauan yang berlebih pada saat musim hujan, sehingga dapat digunakan sewaktu-waktu pada saat musim kemarau.

3. Memanfaatkan pakan hijauan pada saat kondisi dengan nilai nutrisi terbaik seperti protein yang tinggi.

4. Mendayagunakan sumber pakan dari sisa limbah pertanian ataupun hasil agroindustri pertanian dan perkebunan seperti bekatul, dedak, bungkil sawit, ampasa tahu,tumpi jagung, janggel jagung.

\section{Proses Membuat silase:}

\section{Bahan-bahan yang perlu dipersiapkan:}

1. Tetes tebu(molasses) $=3 \%$ dari bahan silase

2. Dedak hulus $=5 \%$ dari bahan silase

3. Menir $=3.5 \%$ dari bahan silase

4. Onggok $=3 \%$ dari bahan silase

5. Rumput Gajah atau hijauan sebagai bahan silase

6. Silo atau kantong plastik.

\section{Cara membuat Silase}

1. Potong rumput hijau tersebut dengan ukuran 5-10 cm dengan menggunakan parang, atau dengan menggunakan mesin chopper. Potongan rumput yang kecil tujuannya agar rumput yang dimasukkan dalam silo dalam keadaan rapat dan padat sehingga tidak ada ruang untuk oksigen dan air yang masuk.

2. Campurkan bahan pakan tersebut hingga menjadi satu campuran. 
3. Bahan pakan ternak tersebut dimasukkan dalam silo dan sekaligus dipadatkan sehingga tidak ada rongga udara.

4. Bahan pakan ternak dimasukkan sampai melebihi permukaan silo untuk menjaga kemungkinan terjadinya penyusutan isi dari silo. Dan tidak ada ruang kosong antara tutup silo dan permukaan pakan paling atas.

5. Setelah pakan hijauan dimasukkan semua, diberikan lembaran plastik, dan ditutup rapat, dan diberi pemberat seperti batu, atau kantong plastik, atau kantong plastic yang diisi dengan tanah.

\section{Cara pengambilan silase}

1. Sesudah enam sampai delapan (6-8) minggu proses ensilase telah selasai, dan silo dapat dibongkar, selanjutnya diambil ensilasenyas. Proses silase yang benar dapat bertahan satu sampai dua (1-2) tahun, bahjkan lebih.

2. Pengambilan silase secukupnya untuk pakan ternak, contonya untuk 3-5 hari.

3. Silase yang baru dibongkar sebaiknya dijemur atau diangin-anginkan terlebih dahulu.

4. Jangan sering-sering membuka silo untuk mengabil silase, ambil seperlunya, dan tutup rapat kembali silasesnya, agar silesa tidak mudah rusak

\section{Ciri-ciri silase yang baik.}

1. Rasa dan wanginya asam

2. Warna pakan ternak masih hijau

3. Teskstur rumput masih jelas

4. Tidak berjamur, tidak berlendir, dan mengumpal

\section{KESIMPULAN DAN SARAN}

\section{Kesimpulan:}

Antusiasme Petani peternak Desa Leu untuk mengikuti penyluhan cukup tinggi dan meningkatnya pemahaman dampak lingkungan akibat tidak dimanfaatkannya limbah pertanian seperti jerami jagung secara efektif dan efisien. Meningkatnya pengetahuan petani peternak Desa Leu tentang cara pengawetan dan mengolah limbah jerami jagung sebagai pakan ternak.

\section{Saran}

Perlu adanya pendampingan secara kontinyu untuk memastikan apa yang telah di suluhkan dapat diterapkan dalam pengembangan peternakan selanjutnya.

\section{Ucapan Terima Kasih}

Terima kasih yang sebesar besarnya kami sampaiakan kepada Rektor Universitas Mataram dan Lembaga Penelitian dan Pengabdian Kepada Masyarakat atas dukungan dana dalam pelaksanaan kegiatan ini, serta semua pihak yang secara langsung maupun tidak langsung membantu kelancaran pelaksanaan pengabdian ini. 


\section{DAFTAR PUSTAKA}

Anonimous, 2017. Cara Membuat Silase Untuk Pakan Ternak. https://pakanternak.fapet.ugm.ac.id/2017/10/19/cara-membuat-silase-untuk-pakan-ternak/

Mayasari, N., Yulianti, A., Mushawir, A., 2013. Pemberdayaan Masyarakat Melalui Pemanfaatan Produk Jagung Sebagai Pakan Ternak Di Desa Ciliang dan Cintaratu, Kecamatan Parigi, Kabupaten Ciamis. Dharmakarya Vol. 2 No 1

Novrariani, Nur. 2017. Pengaruh Penggunaan Jerami Jagung Sebagai Pengganti Rumput Lapangan Dalam Ransum Terhadap Kecernaan Fraksi Serat (NDF, ADF, Selulosa dan Hemilulosa) Secara in Vitro. Skripsi. Fakultas Peternakan Universitas Andalas

Paath, R.H., Kaligis, D.A., Kaunang, C.L., 2012. Produksi dan Kualitas Jerami Jagung Sebagai Pakan Ternak Sapi Di Kabupaten Minahasa Selatan. Eugenia Volume 18 No. 1.

Umela, Syaiful. 2016. Daya Dukung Jerami Jagung Sebagai Pakan Ternak Sapi Potong. Politeknik Gorontalo. Gorontalo. 